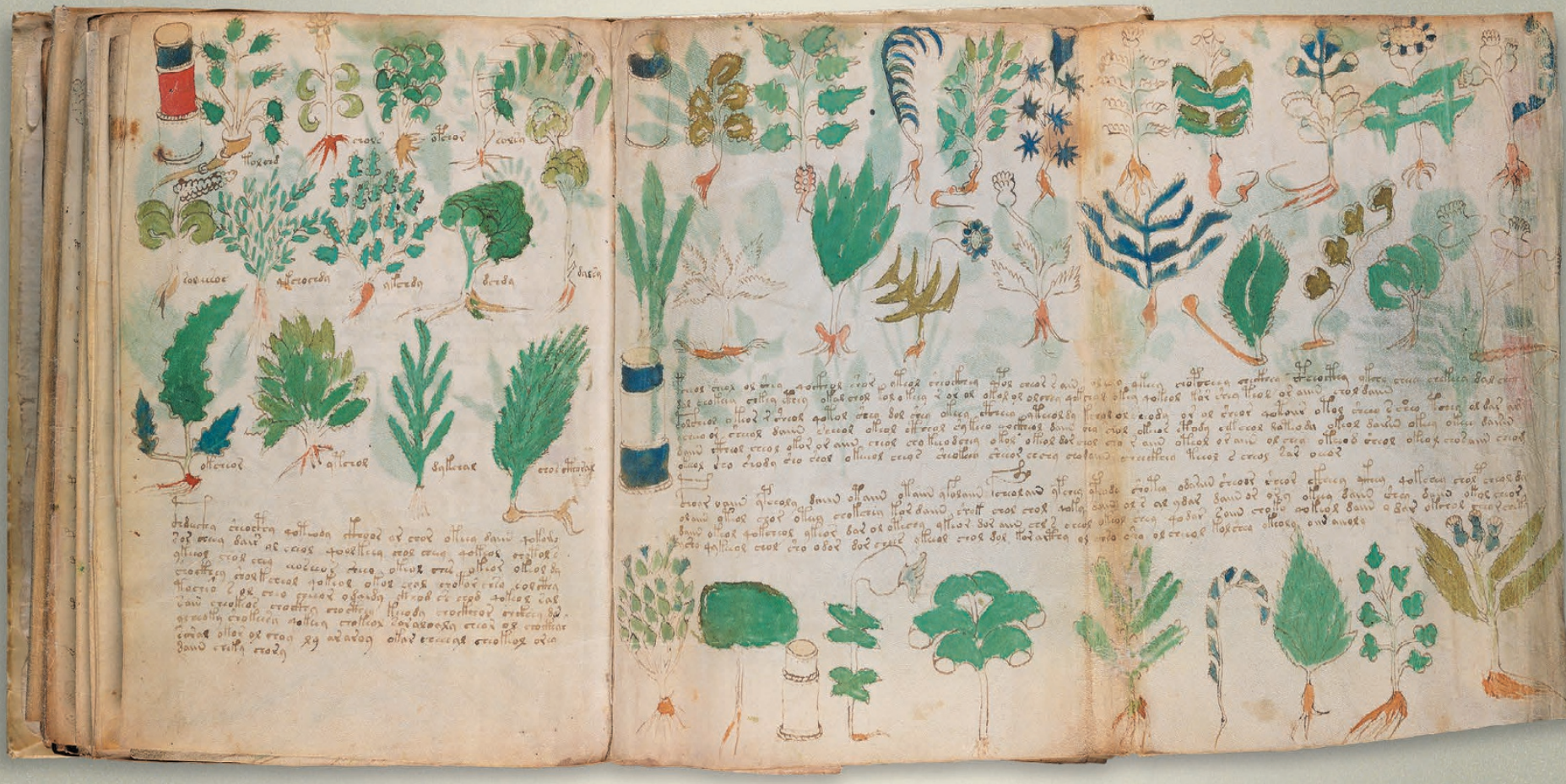

Pages from the 'herbal' section of the Voynich manuscript.

CRYPTOGRAPHY

\title{
Calligraphic conundrum
}

\section{Andrew Robinson relishes a new volume on a work that has long defied decoders.}

$\mathbf{I}_{\text {ithen }}^{\mathrm{n}}$ $n$ a Connecticut archive sits a manuscript justifiably called the most mysterious in the world. Since its rediscovery more than a century ago, the Voynich manuscript has been puzzled over by experts ranging from leading US military cryptographer William Friedman to cautious (and incautious) humanities scholars. Since 1969, it has been stored in Yale University's Beinecke Rare Book and Manuscript Library in New Haven.

The fine calligraphy of the 234-page 'MS 408', apparently alphabetic, has never been decoded. Copious illustrations of bathing women, semi-recognizable plants and apparent star maps remain undeciphered. No one knows who created it or where, and there is no reliable history of ownership. Its parchment was radiocarbon-dated in 2009 to between 1404 and 1438, with 95\% probability. The manuscript could still be a forgery using medieval parchment, but most experts, including Yale's, are convinced it is genuine.

Now The Voynich Manuscript, a volume edited by the library's curator, Raymond Clemens, revivifies this tantalizing artefact. A handsome facsimile is accompanied by an introduction by historian of science Deborah Harkness and six up-to-date essays by conservators, historians and literary scholars. As Harkness remarks, the collection does not attempt a definitive solution of the conundrums raised by the manuscript. Instead, the contributors "invite the reader to join us at the heart of the mystery as we strive to better understand this complex book and its history".

The manuscript is named after Wilfrid Voynich, a Polish-born revolutionary who

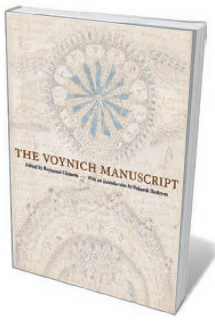

The Voynich Manuscript EDITED BY RAYMOND CLEMENS Yale University Press: 2016. escaped Siberian exile to become a dealer in rare books and manuscripts in London and then New York City. In 1912, under condition of absolute secrecy, Voynich bought the manuscript from a Jesuit archive in Italy that he never identified, but that was selling part of its collection to the Vatican Library. Up to his death in 1930, Voynich marketed it as the work of thirteenth-century English scientist and friar Roger Bacon - a theory discredited only by the radiocarbon dating. In 1961, the manuscript was purchased by book dealer Hans Kraus, who presented it to Yale; the university put it online in 2004 (see go.nature.com/2dlns1c). Today, it attracts
$16 \%$ of traffic to the Beinecke digital library, and for close to half of all traffic to the zoom viewer that allows examination of individual pages of manuscripts. When the late semiotician and novelist Umberto Eco visited Yale in 2013, MS 408 was the only manuscript he asked to see, notes Clemens.

The high-quality colour facsimile makes up most of the book. Each page, including foldouts, is reproduced at almost its original size (around $23 \times 16$ centimetres). Among the essays, researcher René Zandbergen covers the disputed history of the manuscript's ownership from the fifteenth century to 1912. Manuscript curator Arnold Hunt looks at Voynich's respected, but not always scrupulous, career. A group of six conservators details the forensic investigation of the parchment, ink and binding. And historian Jennifer Rampling probes the relationship of the illustrations to those in alchemical manuscripts, finding "no clear parallel" in alchemical writing to the predominance of female bathers.

The story of the various failed attempts to decipher the script, told by Clemens and Renaissance scholar William Sherman, is particularly fascinating. It begins in the 1920s, when US philosopher William Newbold convinced himself that the text was meaningless, but that each letter concealed an 
ancient Greek shorthand readable under magnification. He further claimed that

this 'finding' proved the authorship of Bacon, who he claimed had invented a microscope centuries before Antonie van Leeuwenhoek. After Newbold's death, the 'shorthand' was revealed to be random cracks left by drying ink.

Wisely, little space is devoted to the many speculative theories of origin and meaning. The manuscript has been cast, for instance, as a Middle High German hygiene manual written in 'mirror writing' - the technique used by Leonardo da Vinci - and as a herbal manuscript in the Aztec language Nahuatl. (Readers with a taste for these can consult The Voynich Manuscript (Orion, 2004), a study by Gerry Kennedy and Rob Churchill.) And no new decipherment is offered.

Some idea of the complexity of the story is shown by a letter in Latin that Voynich apparently found affixed to the manuscript. This is reproduced in the volume, oddly without translation. Dated 1665, it was written by Johannes Marcus Marci (physician to the Holy Roman Emperors) and addressed to his former tutor, the Jesuit Athanasius Kircher. (The foremost polymath of the age, Kircher was wrongly credited with deciphering Egyptian hieroglyphs.) In the letter, Marci notes that he is sending Kircher the entire manuscript, asks him to decode it and mentions the claim that Bacon authored it. We know that Kircher received the manuscript, but made no progress with it. After his death in 1680, it disappeared into Jesuit archives in Rome until it came into Voynich's hands.

What hope is there of decoding the script? Not much at present, I fear. The Voynich manuscript reminds me of another uncracked script, on the Phaistos disc from Minoan Crete, discovered in 1908. The manuscript offers much more text to analyse than does the disc, but in each case there is only one sample to work with, and no reliable clue as to the underlying language - no equivalent of the Rosetta Stone (A. Robinson Nature 483, 27-28; 2012). Professional cryptographers have been rightly wary of the Voynich manuscript ever since the disastrous selfdelusion of Newbold. But inevitably, many sleuths will continue to attack the problem from various angles, aided by this excellent facsimile. Wide margins are deliberately provided for readers' notes on their own ideas. "Bonne chance!" writes Clemens. I'll second that.

Andrew Robinson's many books include The Man Who Deciphered Linear B and Lost Languages.

e-mail:andrew@andrew-robinson.org

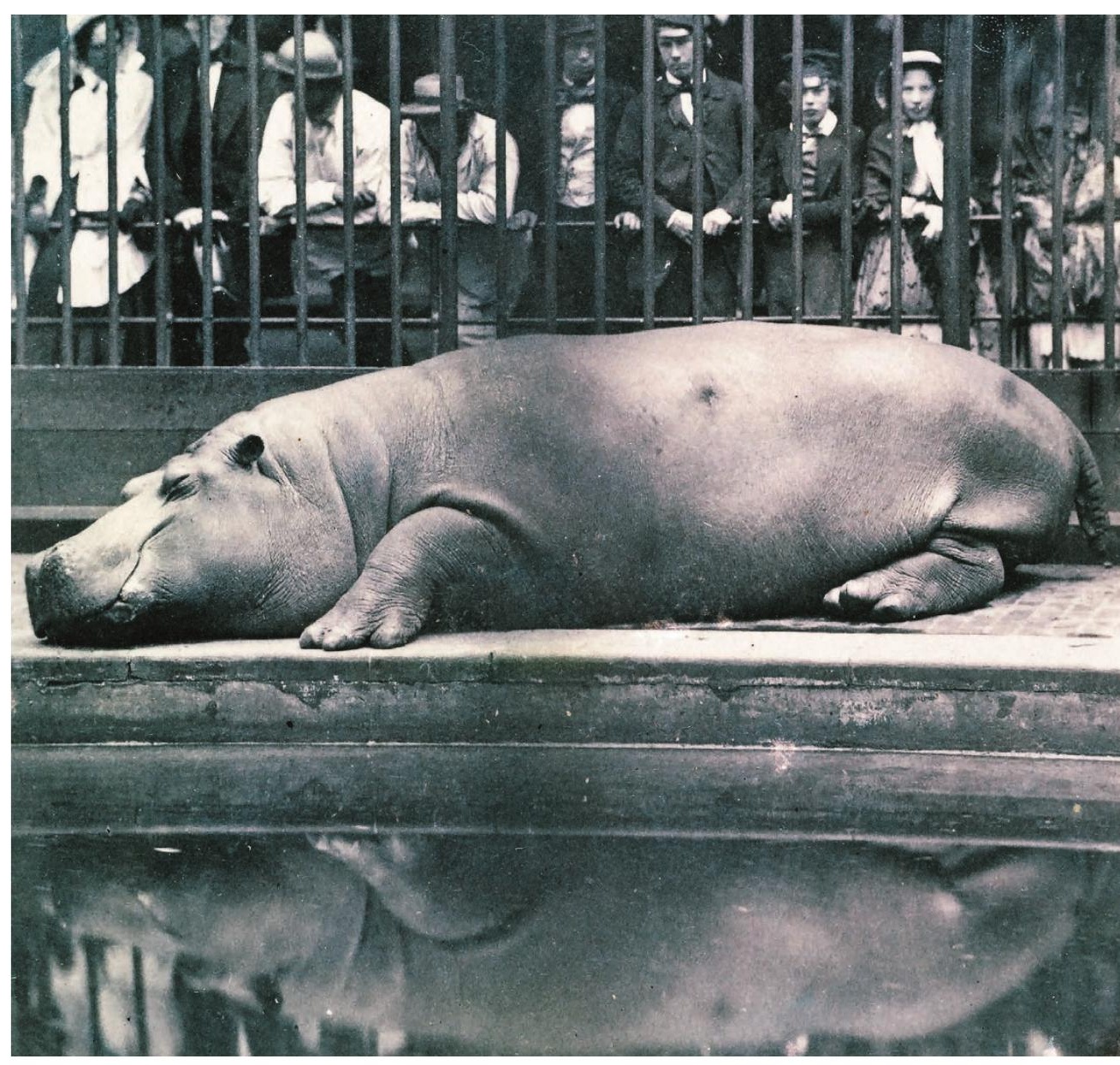

Obaysch the hippo was captured in 1849 and sent to London Zoo, where he became a sensation.

ZOOLOGY

\section{Animal crackers}

\section{Henry Nicholls relishes a brace of chronicles on how zoos on both sides of the Atlantic came to be.}

S tamford Raffles did not waste his time. In 1825 , little more than six months after returning to London from the East Indies, he'd put together a prospectus that would result in the creation of the Zoological Society of London (ZSL). With his career as an entrepreneur-cum-statesman in Penang, Java, Sumatra and Singapore behind him, Raffles was ready to indulge his passion for natural history.

The relationship between humans and the rest of the animal kingdom has always changed and will always change. But there can be few shifts as rapid and radical as those in the nineteenth century. With the age of sail in full swing and European docksides piled with boxes of specimens, a new class of professional zoologist arose. The likes of Alexander von Humboldt, Charles Darwin and Alfred Russel Wallace began to make sense of the
The Zoo: The Wild and Wonderful Tale of the Founding of London Zoo

ISOBEL CHARMAN

Viking: 2016.

The Animal Game: Searching for Wildness at the American Zoo

DANIEL E. BENDER

Harvard University Press: 2016.

astounding variety of animal life. The period covered in Isobel Charman's The Zoo, 182451 , saw much of the transformative action. Meanwhile, historian Daniel Bender's The Animal Game chronicles the evolution of the US zoo from the 1870s to the 1970s.

Charman has hit on a delightful structure for her "wild and wonderful tale". Each chapter is a leg in a relay. So Raffles hands over to Decimus Burton, the ambitious twentysomething architect who began to shape 